\title{
Kajian Eksperimen Kapasitas dan Efisiensi Perontokan pada Power Thresher dengan Variasi Kecepatan Putar dan Jumlah Gigi Silinder Perontok
}

\author{
Suhendra ${ }^{1^{*}}$, Muliadi $^{2}$, Iman Syahrizal ${ }^{3}$, Ari Rianto ${ }^{4}$ \\ Jurusan Teknik Mesin, Politeknik Negeri Sambas ${ }^{1,2,3,4}$ \\ Jl. Raya Sejangkung, Sambas, Kalimantan Barat, Indonesia \\ Email: aka.suhendra@yahoo.com¹, muliadi123@yahoo.com², \\ imansyahrizal123@yahoo.com ${ }^{3}$, aririanto123@yahoo.com ${ }^{4}$
}

\begin{abstract}
Abstrak
Penerapan teknik perontokan yang kurang tepat dapat meningkatkan kehilangan hasil. Proses perontokan secara umum dapat dilakukan menggunakan cara manual dan mekanis. Perontokan secara mekanis dilakukan menggunakan thresher dengan mekanisme perontok berupa gigi yang terpasang pada silinder perontok. Gigi perontok terbuat dari baut atau besi bulat padat biasanya dapat diatur tinggi rendahnya. Pergerakan silinder perontok dapat dihasilkan secara manual menggunakan engkol pemutar atau menggunakan engine. Kecepatan putar dan jumlah gigi pada silinder perontok merupakan parameter yang memiliki pengaruh terhadap hasil perontokan, karena parameter tersebut sering divariasikan oleh petani saat melakukan proses perontokan. Penelitian ini bertujuan untuk melakukan uji kinerja pada power thresher dan membuktikan pengaruh kecepatan putar dan jumlah gigi silinder perontok terhadap kapasitas dan efisiensi perontokan pada padi varietas Sirendah. Kecepatan putar silinder perontok divariasikan menjadi 4 perlakuan yaitu 364, 446, 476 dan $512 \mathrm{rpm}$. Jumlah gigi pada silinder perontok divariasikan menjadi 4 perlakuan yaitu 40, 52, 60 dan 68 buah. Variabel tak bebas penelitian meliputi kapasitas dan efisiensi perontokan gabah pada power thresher. Berdasarkan hasil pengujian kecepatan putar silinder perontok pada power thresher sangat berbeda nyata pengaruhnya terhadap kapasitas perontokan gabah, sedangkan jumlah gigi silinder perontok sangat berbeda nyata pengaruhnya terhadap efisiensi perontokan gabah. Interaksi perlakuan kecepatan putar $512 \mathrm{rpm}$ dan gigi silinder perontok berjumlah 68 buah menghasilkan kapasitas perontokan terbaik yaitu $569 \mathrm{~kg} / \mathrm{jam}$. Interaksi perlakuan jumlah gigi perontok 52 buah pada kecepatan putar silinder perontok $446 \mathrm{rpm}$ menghasilkan efisiensi perontokan terbaik yaitu sebesar 95,3\%.
\end{abstract}

Kata kunci: Gigi perontok, kecepatan putar, perontok gabah.

\section{Pendahuluan}

Padi (Oryza sativa) merupakan tanaman penghasil beras sebagai makanan pokok penduduk Indonesia. Meningkatnya pertumbuhan pendudukan berbanding lurus terhadap permintaan beras. Peningkatan produksi dapat dilakukan dengan memperluas areal tanam padi atau dengan meminimalisasi kehilangan hasil ketika proses panen atau pascapanen. Kehilangan hasil selama penanganan panen dan pascapanen dapat mencapai 20$21 \%$, terjadi pada pemanenan padi sekitar 9\% dan pada perontokan sekitar 5\% [1]. Data lain menyebutkan kehilangan hasil saat panen dan pascapanen dapat mencapai $20,5 \%$ dengan kehilangan pada saat pemanenan $9,52 \%$, perontokan $4,78 \%$, pengeringan $2,13 \%$, penggilingan $2,19 \%$, penyimpanan $1,16 \%$, dan pengangkutan $0,19 \%$ [2]. Kehilangan hasil dapat disebabkan oleh tercecernya gabah atau beras ketika proses panen dan pascapanen dilakukan.

Kegiatan panen merupakan semua proses kegiatan yang dilakukan di lahan (on farm), sedangkan kegiatan pascapanen adalah semua proses kegiatan yang dilakukan di luar lahan (off farm). Kegiatan panen padi dimulai dengan 
kegiatan perontokan bulir padi dari batang dan kegiatan perontokan padi. Proses pascapanen meliputi kegiatan pengeringan, pembersihan dan penggilingan gabah [3]. Di beberapa daerah, proses perontokan dilakukan beberapa hari setelah panen dilakukan dan tidak dilakukan di lahan sawah, sehingga proses perontokan terkadang dapat dikategorikan sebagai proses pascapanen.

Salah satu kegiatan yang memiliki peran penting dalam mengurangi kehilangan hasil padi adalah teknik perontokan yang tepat. Perontokan merupakan proses pemisahan butir gabah dari tangkai malainya. Perontokan dapat dilakukan dengan cara manual atau menggunakan mekanisme tertentu. Prinsip dasar perontokan adalah membenturkan butir gabah pada tangkai malai dengan mekanisme perontok sehingga butir gabah terlepas dari tangkainya.

Proses perontokan secara umum dilakukan menggunakan gebot dan cara mekanis. Gebot adalah proses perontokan dengan membantingkan malai padi pada kayu atau rangka bambu untuk melepaskan gabah dari malainya. Cara mekanis yaitu menggunakan thresher dengan 4 mekanisme perontokan meliputi stripping (serut), hammering (pukul), impact (tabrakan) dan kombinasi dari mekanisme tersebut [3]. Proses perontokan menggunakan cara mekanis dapat menghasilkan kapasitas, efisiensi dan kualitas perontokan yang jauh lebih tinggi dibanding cara manual.

Berbagai penelitian tentang proses perontokan telah dilakukan untuk mendapatkan hasil perontokan terbaik menggunakan mesin perontok. Penelitian tentang uji kinerja mesin perontok multiguna telah dilakukan pada padi varietas Ciherang dan Bestari untuk mengetahui kapasitas perontokan, efisiensi perontokan, dan kualitas perontokan [4]. Penelitian lain membahas tingkat susut dan kualitas gabah pada padi varietas Ciherang, Cibogo, dan Hibrida dengan berbagai mekanisme perontokan [5].
Berdasarkan kondisi tersebut, perlu dilakukan penelitian khusus jenis varietas padi yang masih belum diteliti. Jenis padi yang digunakan dalam penelitian ini adalah varietas Sirendah. Varietas Sirendah termasuk varietas padi lokal yang paling luas sebarannya di Kalimantan Barat [6]. Varietas ini merupakan salah satu varietas yang banyak dibudidayakan oleh petani di Kabupaten Sambas.

Penelitian yang dilakukan adalah melakukan uji kinerja power thresher pada padi varietas Sirendah. Tujuan penelitian ini adalah membuktikan pengaruh kecepatan putar dan jumlah gigi silinder perontok terhadap kapasitas dan efisiensi perontokan pada padi varietas Sirendah.

\section{Tinjauan Pustaka}

Proses perontokan yang dilakukan oleh petani di Kabupaten Sambas umumnya dilakukan beberapa hari setelah panen dilakukan. Petani akan menumpuk dan mengumpulkan padi terlebih dahulu baru kemudian melakukan proses perontokan.

Teknik yang umum dipakai dalam proses perontokan padi adalah menggunakan cara tradisional dan dengan mesin perontok. Cara tradisional yaitu menggunakan gebot menghasilkan kapasitas perontokan dibawah $100 \mathrm{~kg} / \mathrm{jam}$ dengan persentase gabah yang tidak terontok berkisar antara $6 \%-9 \%$. Jenis mesin perontok (thresher) yang biasa digunakan adalah jenis pedal thresher dan thresher lipat, thresher tipe drum (silinder) tertutup, thresher tipe drum (silinder) terbuka, thresher tipe drum (silinder) terbuka yang telah dimodifikasi, thresher mobil tipe aksial dan thresher modifikasi untuk varietas padi ulet [3].

Power thresher yang banyak digunakan oleh petani di Kabupaten Sambas adalah adalah jenis thresher tipe drum (silinder) terbuka yang telah dimodifikasi. Modifikasi pada power thresher adalah penambahan pada roda untuk memudahkan transportasi di lahan. 
Kapasitas kerja power thresher jenis ini berkisar antara $500-600 \mathrm{~kg} / \mathrm{jam}$.

Jenis padi yang digunakan dalam penelitian adalah varietas Sirendah. Varietas Sirendah tersebar di 6 Kabupaten meliputi Kabupaten Sambas, Pontianak, Kubu Raya, Bengkayang, Landak dan Kapuas Hulu [6]. Umur panen padi varietas Sirendah sekitar 136 hari dan termasuk jenis varietas yang tahan terhadap kerontokan [7].

Varietas padi sangat menentukan efisiensi perontokan gabah. Beberapa varietas padi memiliki daya tahan terhadap kerontokan. Padi varietas ini cenderung tidak mudah hilang atau tercecer di lokasi saat proses panen. Namun pada proses perontokan, varietas ini memerlukan tenaga perontokan yang lebih besar dibanding padi varietas yang mudah dirontokan. Berdasarkan daya kerontokan padi, dapat diklasifikasikan kedalam tingkat tahan rontok, sedang serta mudah rontok [8].

Kapasitas perontokan adalah banyaknya massa butir gabah yang lepas dari malainya per satuan waktu. Satuan kapasitas perontokan yang umumnya digunakan adalah $\mathrm{kg} / \mathrm{jam}$. Efisiensi perontokan adalah perbandingan antara butir atau massa gabah yang terlepas dari malai dengan butir atau massa gabah yang dimasukkan dalam power thresher dan hasilnya dinyatakan dalam satuan persen. Perhitungan efisiensi perontokan dilakukan dengan terlebih dahulu memisahkan gabah yang terlepas dan gabah yang tidak terlepas dari malai padi.

Metode yang umum dipakai untuk melakukan penelitian eksperimen adalah menggunakan rancangan percobaan. Rancangan percobaan merupakan teknik pengujian dimana perubahan yang berarti dilakukan pada variabel dari suatu proses atau sistem sehingga kita dapat mengamati dan mengidentifikasi alasan-alasan perubahan pada respon output. Tujuan menerapkan rancangan percobaan dalam suatu penelitian adalah untuk memperbaiki proses hasil, mengurangi keragaman, mengurangi waktu penelitian dan menekan biaya yang dikeluarkan dalam penelitian [9].

\section{Metode Penelitian}

Alat yang digunakan dalam pengujian adalah power thresher tipe drum (silinder) terbuka yang telah dimodifikasi, tachometer, stopwatch, timbangan, terpal plastik dan wadah. Bahan yang digunakan dalam pengujian adalah padi varietas Sirendah. Teknik panen untuk mengambil sampel adalah menggunakan ani-ani. Pemotongan dilakukan pada bagian atas tangkai malai padi dengan panjang sekitar $30 \mathrm{~cm}$.

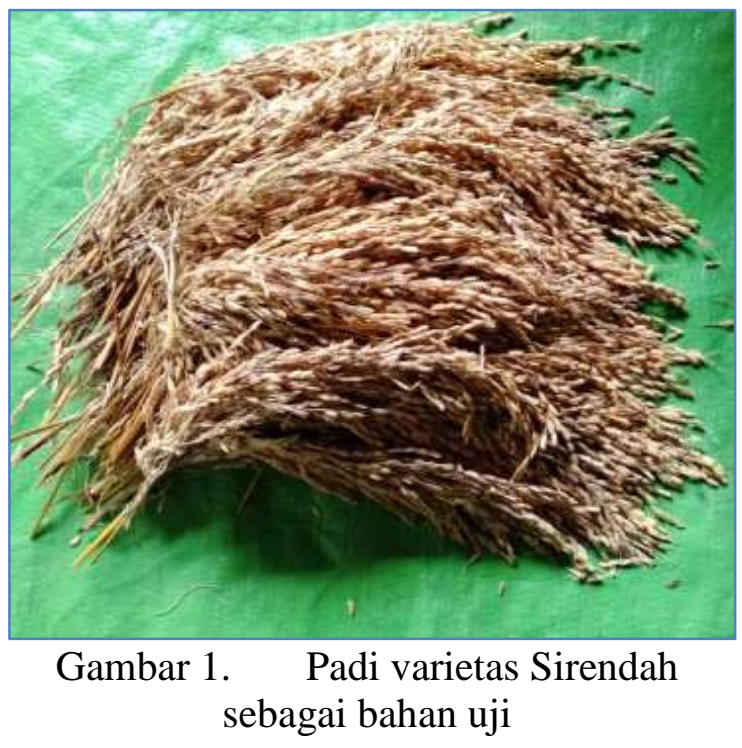

Prosedur pengujian dilakukan dengan menentukan variabel bebas (independent variable) dan variabel tak bebas (dependent variable) penelitian. Variabel bebas penelitian adalah kecepatan putar dan jumlah gigi pada silinder perontok. Kecepatan putar silinder perontok divariasikan menjadi 4 perlakuan yaitu 364, 446, 476 dan 512 rpm. Jumlah gigi pada silinder perontok divariasikan menjadi 4 perlakuan yaitu 40, 52, 60 dan 68 buah. Variabel tak bebas meliputi kapasitas dan efisiensi perontokan gabah pada power thresher. Massa sampel padi untuk 1 kali pengujian ditetapkan sebanyak $10 \mathrm{~kg}$. Pengambilan data untuk setiap kombinasi perlakuan dilakukan dengan pengulangan sebanyak 3 kali. 
Pengujian dalam penelitian ini menggunakan metode rancangan acak kelompok lengkap (RAKL) 2 faktor. Langkah pengujian adalah membuat plot pengacakan, mengacak setiap perlakuan, memasukkan hasil pengacakan ke dalam plot pengacakan dan melakukan pengujian untuk mendapatkan data penelitian sesuai dengan pengacakan yang telah dibuat.

Prosedur pengujian dilakukan dengan terlebih dahulu menimbang padi sebagai sampel uji. Atur jumlah gigi pada silinder perontok sesuai dengan yang diinginkan kemudian hidupkan mesin thresher. Atur kecepatan putar silinder perontok sesuai kebutuhan dengan mengatur pembukaan saluran bahan bakar. Nilai kecepatan putar silinder perontok diukur menggunakan tachometer. Masukan sampel uji ke dalam power thresher lalu hitung waktu proses perontokkan sampai selesai menggunakan stopwatch. Kumpulkan seluruh data hasil pengujian, selanjutnya hitung kapasitas dan efisiensi perontokan.

Kapasitas perontokan gabah pada power thresher dapat dihitung menggunakan persamaan berikut [10] :

$$
K=\frac{B g}{t} \times 3.600
$$

Keterangan:

$\mathrm{K}=$ Kapasitas perontokan ( $\mathrm{g} / \mathrm{jam})$

$\mathrm{Bg}=$ Berat gabah yang dihasilkan $(\mathrm{g})$

$\mathrm{t}=$ Waktu yang dibutuhkan (detik)

Efisiensi perontokan gabah pada power thresher dapat dihitung menggunakan persamaan berikut [10] :

$$
\eta P=\frac{B_{G R}}{B_{G R}+B_{G R T}} \times 100 \%
$$

Keterangan:

$\eta P \quad=$ Efisiensi perontokan $(\%)$

$\mathrm{B}_{\mathrm{GR}}=$ Butir gabah terontok (butir)

$\mathrm{B}_{\mathrm{GRT}}=$ Butir gabah tak terontok (butir)

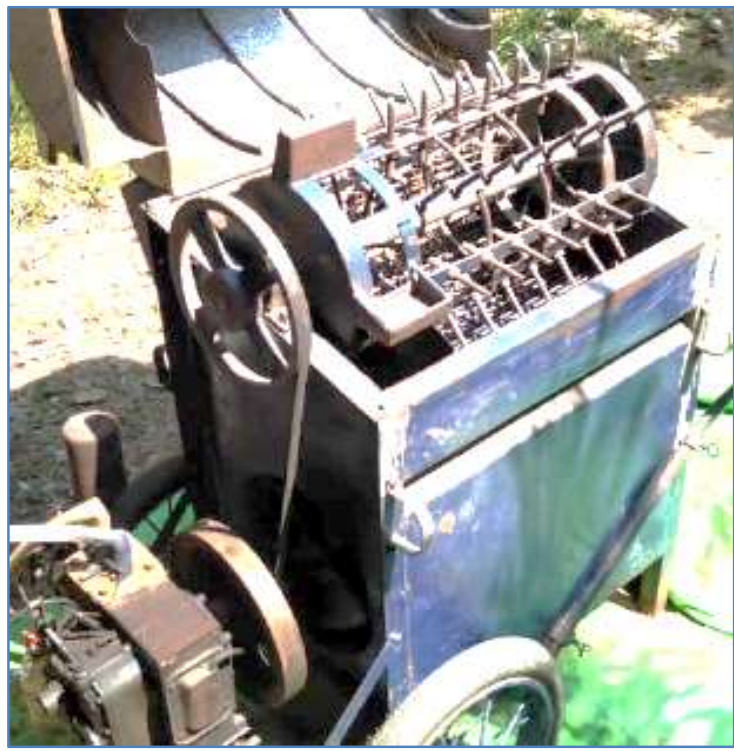

Gambar 2. Power thresher yang dipakai untuk pengujian

Data hasil pengujian selanjutnya dianalisis menggunakan analisis sidik ragam (ANOVA). Analisis data digunakan untuk mengetahui pengaruh antara variabel bebas dan variabel tak bebas. Hasil analisis tersebut dapat digunakan untuk membuat kesimpulan hubungan antara variabel.

\section{Hasil dan Pembahasan}

Hasil perhitungan rata-rata jumlah butir gabah per malai pada padi varietas sirendah diperoleh sebanyak 236 butir gabah per malai dengan jumlah sampel sebanyak 100 malai. Data jumlah butir gabah per malai digunakan untuk menghitung efisiensi perontokan gabah berdasarkan persamaan 2 .

Power thresher yang digunakan dalam pengujian adalah perontok yang biasa digunakan oleh petani di Desa Samustida Kecamatan Teluk Keramat Kabupaten Sambas untuk merontok padi. Power thresher ini merupakan tipe drum (silinder) terbuka yang telah dimodifikasi dengan penggerak mesin diesel 5,5 PK.

Pengujian power thresher dilakukan untuk mengetahui pengaruh kecepatan putar dan jumlah gigi perontok pada silinder terhadap kapasitas dan efisiensi perontokan gabah. Hasil pengujian dicatat dan dianalisis untuk mengetahui hubungan antar variabel yang diuji. 


\section{Uji kinerja kapasitas power tresher}

Hasil uji statistik menunjukkan bahwa kecepatan putar silinder perontok pada power thresher sangat berbeda nyata pengaruhnya terhadap kapasitas perontokan gabah, sedangkan jumlah gigi silinder perontok tidak berbeda nyata pengaruhnya terhadap kapasitas perontokan gabah. Data lengkap hasil pengujian hubungan kecepatan putar dan jumlah gigi silinder perontok terhadap rata-rata kapasitas perontokan gabah dapat dilihat pada Tabel 1.

Tabel 1. Hasil pengujian kecepatan putar dan jumlah gigi silinder perontok terhadap rata-rata kapasitas perontokan $(\mathrm{kg} / \mathrm{jam})$

\begin{tabular}{ccc}
\hline $\begin{array}{c}\text { Jumlah gigi } \\
\text { perontok }\end{array}$ & $\begin{array}{c}\text { Kecepatan } \\
\text { putar (rpm) }\end{array}$ & $\begin{array}{c}\text { Kapasitas } \\
\text { perontokan } \\
\text { (kg/jam) }\end{array}$ \\
\hline \multirow{4}{*}{ 40 buah } & 364 & 440 \\
& 446 & 450 \\
& 476 & 474 \\
52 buah & 512 & 517 \\
\hline \multirow{5}{*}{60 buah } & 364 & 360 \\
& 446 & 414 \\
& 476 & 484 \\
& 512 & 546 \\
\hline 68 buah & 364 & 414 \\
& 476 & 434 \\
& 512 & 462 \\
& 364 & 543 \\
\hline
\end{tabular}

Berdasarkan hasil pengujian, kecepatan putar $512 \mathrm{rpm}$ menghasilkan rata-rata kapasitas perontokan yang lebih baik dibanding kecepatan putar 364, 446 dan $476 \mathrm{rpm}$. Jumlah gigi perontok 40 dan 68 buah menghasilkan rata-rata kapasitas perontokan yang hampir sama dan lebih baik dibanding jumlah gigi perontok 52 dan 60 buah.

Hasil uji kinerja terbaik untuk perontokan gabah diperoleh pada interaksi perlakuan kecepatan putar $512 \mathrm{rpm}$ dan gigi silinder perontok berjumlah 68 buah dengan rata-rata kapasitas perontokan 569 $\mathrm{kg} / \mathrm{jam}$.

Hasil pengujian menunjukkan bahwa peningkatan kecepatan putar silinder perontok pada power thresher dapat meningkatkan kapasitas perontokan gabah sedangkan penambahan jumlah gigi perontok relatif tidak mempengaruhi kapasitas perontokan gabah. Semakin tinggi putaran pada silinder perontok menyebabkan proses perontokan pada gabah semakin cepat berlangsung sehingga waktu keluar gabah pada power thresher semakin singkat.

Kecepatan putar silinder perontok yang terlalu tinggi dapat meningkatkan resiko rusaknya butir gabah hasil perontokan, sehingga diperlukan kecepatan putar yang sesuai agar diperoleh hasil perontokan yang optimal.

Kecepatan putar silinder perontok terbaik hasil pengujian mendekati hasil yang direkomendasikan oleh Ditjen PPHP Deptan. Kecepatan putar silinder perontok pada power thresher yang direkomendasikan berada pada kecepatan putar 400-450 rpm [11].

\section{Uji Kinerja Efisiensi Power Tresher}

Hasil uji statistik menunjukkan bahwa jumlah gigi silinder perontok sangat berbeda nyata pengaruhnya, sedangkan kecepatan putar silinder perontok tidak berbeda nyata pengaruhnya terhadap efisiensi perontokan pada power thresher. Data lengkap hasil pengujian hubungan kecepatan putar dan jumlah gigi silinder perontok terhadap rata-rata efisiensi perontokan dapat dilihat pada Tabel 2 .

Berdasarkan hasil pengujian, jumlah gigi 52 buah pada silinder perontok menghasilkan rata-rata efisiensi perontokan yang lebih baik dibanding jumlah gigi 40, 60 dan 68 buah. Rata-rata efisiensi perontokan pada jumlah gigi perontok 52 buah diperoleh sebesar 93,9\%, sedangkan variasi kecepatan putar pada silinder perontok menghasilkan rata-rata efisiensi perontokan yang hampir sama. 
Tabel 2. Hasil pengujian kecepatan putar dan jumlah gigi silinder perontok terhadap rata-rata efisiensi perontokan $(\%)$

\begin{tabular}{ccc}
\hline $\begin{array}{c}\text { Jumlah gigi } \\
\text { perontok }\end{array}$ & $\begin{array}{c}\text { Kecepatan } \\
\text { putar (rpm) }\end{array}$ & $\begin{array}{c}\text { Efisiensi } \\
\text { perontokan } \\
(\%)\end{array}$ \\
\hline \multirow{4}{*}{40 buah } & 364 & 92,8 \\
& 446 & 92,7 \\
& 476 & 92,7 \\
& 512 & 92,8 \\
\hline \multirow{5}{*}{52 buah } & 364 & 93,0 \\
& 446 & 95,3 \\
60 buah & 476 & 93,9 \\
& 512 & 93,4 \\
\hline \multirow{5}{*}{68 buah } & 364 & 92,9 \\
& 446 & 92,7 \\
& 476 & 92,8 \\
& 512 & 92,8 \\
\hline & 364 & 92,7 \\
& 446 & 92,7 \\
& 512 & 92,8 \\
& & 92,9 \\
\hline
\end{tabular}

Hasil uji kinerja terbaik pada power thresher diperoleh pada interaksi perlakuan jumlah gigi perontok 52 buah pada kecepatar putar silinder perontok 446 rpm dengan rata-rata efisiensi perontokan gabah $95,3 \%$.

Proses perontokan gabah menggunakan power thresher selain dipengaruhi oleh jumlah gigi pada silinder perontok juga dipengaruhi oleh berbagai faktor. Salah satu faktor yang mempengaruhi persentase perontokan gabah adalah varietas padi [5].

\section{Kesimpulan}

Berdasarkan hasil pengujian yang telah dilakukan dapat dibuat kesimpulan bahwa; Kecepatan putar silinder perontok pada power thresher sangat berbeda nyata pengaruhnya terhadap kapasitas perontokan gabah, sedangkan jumlah gigi silinder perontok sangat berbeda nyata pengaruhnya terhadap efisiensi perontokan gabah; Kecepatan putar 512 rpm pada power thresher menghasilkan rata-rata kapasitas perontokan yang paling tinggi, sedangkan jumlah gigi 52 buah pada silinder perontok menghasilkan rata-rata efisiensi perontokan yang paling tinggi. Penambahan kecepatan putar silinder perontok cenderung meningkatkan kapasitas perontokan gabah; Hasil uji kinerja terbaik terhadap kapasitas perontokan gabah diperoleh pada interaksi perlakuan kecepatan putar $512 \mathrm{rpm}$ dan gigi silinder perontok berjumlah 68 buah dengan rata-rata kapasitas perontokan 569 $\mathrm{kg} / \mathrm{jam}$; Hasil uji kinerja terbaik terhadap efisiensi perontokan pada power thresher diperoleh pada interaksi perlakuan jumlah gigi perontok 52 buah pada kecepatan putar silinder perontok $446 \mathrm{rpm}$ dengan efisiensi perontokan $95,3 \%$.

\section{Referensi}

[1]. Ananto E, Setyono A, Sutrisno. Panduan Teknis Penanganan Panen dan Pascapanen Padi dalam Sistem Usahatani Tanaman-Ternak. Bogor: Puslitbangtan; 2003.

[2]. Iswari K. Kesiapan Teknologi Panen Dan Pascapanen Padi Dalam Menekan Kehilangan Hasil Dan Meningkatkan Mutu Beras. Jurnal Litbang Pertanian. 2012;31(2):58-67.

[3]. Sulistiaji K. Alat dan Mesin (Alsin) Panen dan Perontokan Padi di Indonesia. Serpong: Balai Besar Pengembangan Mekanisasi Pertanian, Badan Penelitian dan Pengembangan Pertanian; 2007.

[4]. Iqbal, Suhardi, Nirisnawati SA. Uji Unjuk Kerja Alat dan Mesin Perontok Multiguna. Jurnal Ilmu Rekayasa Pertanian dan Biosistem. 2018;6(1):12-6.

[5]. Hasbullah R, Indaryani R. Penggunaan Teknologi Perontokan untuk Menekan Susut dan Mempertahankan 
Kualitas Gabah. JTEP Jurnal Keteknikan Pertanian. 2009; 23(2):111-8.

[6]. Subekti A, Permana D, W TYA, Muflih MA. Keragaan Plasma Nutfah Padi Lokal di Kalimantan Barat. 2013;72937.

[7]. P3TP. Varietas Unggul, Padi [Internet]. Pusat Penelitian dan Pengambangan Tanaman Pangan. 2013. Available from:

http://pangan.litbang.pertanian .go.id/varietas-489.html

[8]. Herawati H. Mekanisme Dan Kinerja pada Sistem Perontokan Padi. Jurnal Litbang Provinsi Jawa Tengah. 2008;6(2):195-203.

[9]. Montgomery DC. Design and Analysis of Experiments. 9th ed. John Wiley \& Sons, Inc; 2013. 1-681 p.

[10]. SNI. Mesin Perontok Padi, Cara Uji Unjuk Kerja. Badan Standarisasi Nasional; 1989. 1-5 p.

[11]. Deptan. Pedoman Teknis Penanganan Pascapanen dan Pemasaran Gabah. Direktorat Jenderal Pengolahan dan Pemasaran Hasil Pertanian. Departemen Pertanian; 2007. 